\title{
Effect of Iron Supplementation on Plasma Lipid Levels in Pregnant Anemic Women
}

Running Title: Iron Supplementation and Lipid Profiles in Pregnant Women

\author{
Amit Kumar Mani Tiwari ${ }^{1,2}$, Abbas Ali Mahdi ${ }^{2}$, Sanjay Mishra ${ }^{1}$ \\ ${ }^{1}$ School of Biotechnology, IFTM University, Lodhipur Rajput, NH-10, Delhi Road, Moradabad, India \\ ${ }^{2}$ Department of Biochemistry, King George"s Medical University, Lucknow, India
}

Corresponding Author

Prof. Abbas Ali Mahdi

Department of Biochemistry, King George"s Medical University, Lucknow-226003, India

Mobile No: +91- 9839011192, 9415007706

Fax No: (0522) 2257539

Email: mahdiaa@rediffmail.com

\begin{abstract}
Background \& Aims: The present study deals with an investigation on the effect of iron deficiency anemia and iron supplementation on anemia markers and plasma lipid profiles in pregnant women. Methods: A total of 350 pregnant women were taken and divided into four groups on the basis of haemoglobin levels viz. control (100), mild (100), moderate (100) and severe (50) patients. All the groups were treated orally with $100 \mathrm{mg}$ of iron and $500 \mu \mathrm{g}$ of folic acid daily for hundred days. Results: Iron deficient pregnant women reflected a significant increase in plasma low density lipoprotein (LDL), very low density lipoprotein (VLDL), triglyceride (TG), lipid peroxide levels (LPx) and serum transferrin receptor levels (sTfR) while reduced concentration of plasma high density lipoprotein (HDL), iron (Fe), total lipid (TL), total cholesterol (TC) phospholipid (PL), serum ferritin and haemoglobin $(\mathrm{Hb})$ and haematocrit (Hct) levels. Iron supplementation with folic acid indicated reverse changes in plasma Hb, Hct, Fe TL, TC, PL, TfR and ferritin except HDL levels. Moreover, iron treatment increases the rate of LPx, LDL, VLDL and TG levels. Conclusion: Besides, the results entails that iron supplementation returns to $\mathrm{Hb}$ levels but at the cost of lipoprotein oxidation especially in control and base line anemic women. Conclusively data of this study provide new insights into exploring a relationship between iron status and lipoprotein oxidation. However, further studies, including bigger sample size are mandatory to further irresolution of this problem.
\end{abstract}

Keywords: Pregnancy, iron deficiency, iron supplementation, lipid profiles, pregnancy outcome

\section{Introduction}

Iron deficiency is the most widespread micronutrient nutritional deficiency. Women tend to have substantially lower iron stores, making them more vulnerable to iron deficiency when iron intake is lowered or need increases. Iron supplementation is the most widely used approach to controlling the global problem of iron deficiency anemia. It is recognized in terms of excess body iron and "free iron" stimulating lipid peroxidation followed by leading to cell and tissue damage [1-2].

Iron deficiency led anemia is characterized by salient modified features of erythrocytes, including decreased cellular deformability due to anomalies in the structure and function of erythrocyte membrane, microcytosis and hypochromia. Increased susceptibility of these microcytic red blood cells to in vitro oxidative stress has also been demonstrated [3]. Indeed, alterations in proteins and lipids may often be more important in oxidative stress situations in vivo, since they provide the viscoelastic properties essential necessary for membrane deformability [4]. While the length and degree of unsaturation of phospholipid fatty acids particularly influence the lipid bilayer fluidity [5], the proteins and glycophorin play a crucial role in maintaining erythrocyte integrity and antegenecity.
Although studies have pronounced modifications in the erythrocyte membrane structure and function in iron deficiency anemia [6], few and rather conflicting data are available on the Indian population with IDA [7].

Lipid metabolism alters during pregnancy [8]. The anabolic phase of early pregnancy encourages lipogenesis and fat storage in preparation for rapid fetal growth in late pregnancy [9]. Normal pregnancy is associated with the formation of susceptible oxidizable particles (high LDL score) and an increase in oxidative damage. Iron deficiency is an independent risk factor for the development of coronary artery disease and is also associated with the development of an atherogenic lipid profile and increased oxidative stress [10]. Pregnant women with iron deficiency may further amplify these changes. Epidemiological studies have shown that low serum iron-binding capacity and high serum iron concentrations following abnormal levels of blood lipids are risk factors for coronary artery disease (CAD) and myocardial infarction [11-12]. Despite the great deal of information available on the hematological and biochemical changes in iron deficient anemic women, very limited studies have been carried out to investigate the lipid profiles in women with iron deficiency. A study conducted by Choi et al. [13] revealed lipid levels in patients with iron deficiency anemia to be directly related 


\section{International Journal of Science and Research (IJSR) \\ ISSN (Online): 2319-7064 \\ Index Copernicus Value (2013): 6.14 | Impact Factor (2014): 5.611}

to the level of iron. The total cholesterol level in the severely anemic group was observed to be significantly lower than that found in the other group. The triglyceride level was twofold higher in subjects with haemoglobin $>$ $14.0 \mathrm{~g} / \mathrm{dl}$ than in subjects with haemoglobin $<8.0 \mathrm{~g} / \mathrm{dl}$. The serum lipid concentrations in the females with severe anemia were significantly higher after iron supplementation. The study showed that blood haemoglobin levels correlated significantly with serum cholesterol concentrations. The results of the above study were contradicted by a study done accomplished by Tanzer et al. [14], according with higher serum total triglyceride, total cholesterol, and VLDL levels in iron deficient patients than in healthy controls. A study revealed that triglyceride, total HDL and LDL cholesterol levels having been higher during pregnancy except LDLcholesterol that remained constant [15]. There is a study reported that serum triglyceride, total cholesterol LDL-c levels increased gradually as pregnancy proceeded except HDL-c level did not change significantly during pregnancy [16]. Therefore, the present study was undertaken to investigate the changes in iron status, oxidative stress and lipid levels in response to iron deficiency and iron supplementation in pregnant anemic women.

\section{Materials and Methods}

The study was approved by the Institutional Ethical Committee of King George"s Medical University, Lucknow, U.P., India and the objectives of the study were explained and a written concept was taken from each subject. The study was performed in the Department of Biochemistry, King George's Medical University, Lucknow, U.P., India. The present study comprised of 250 pregnant anemic women [viz. mild (100), moderate (100) and severe (50)] aged between 20-40 years and pregnant non-anemic women as control $(100), \mathrm{Hb}$ as $>11 \mathrm{~g} / \mathrm{dl}$ ranging in same age. The subjects were selected amongst those attending the Department of Obstetrics and Gynaecology, King Georgee's Medical University, Lucknow, U.P., India. Care was taken to ensure that all the subjects belonged to middle socioeconomic group (who were able to meet the basic necessities of life and have same requirements of confort). Selected subjects were all consumers of normal mixed Indian diet, not taking any drug for preceding one month. The inclusion criteria of anemic subjects were according to $\mathrm{WHO}$, which defines mild anemia as $\mathrm{Hb} 10.0-10.9 \mathrm{~g} / \mathrm{dl}$, moderate as $\mathrm{Hb} 7.0-9.9$ $\mathrm{g} / \mathrm{dl}$ and severe as $\mathrm{Hb}<7.0 \mathrm{~g} / \mathrm{dl}$ [17]. Exclusion criteria were $\mathrm{Hb}$ less than $6.5 \mathrm{~g} / \mathrm{dl}$, no $\mathrm{Hb}$ rise by $1 \%$ after 3 -week of iron-folic supplementation, alcoholic, smoker, metabolic diseases such as diabetes mellitus, malignancy, heart disease, infections such as tuberculosis, HIV, regularly using minerals/vitamins supplements and endocrine disorders.

\section{Treatment}

Each subject participated in the study for 100 days. At recruitment, all pregnant women (non-anemic and anemic) were first dewormed by giving them a single dose of Albendazole following Metronidazole (400 mg) three times daily for five days. Two days later i.e. after one week of recruitment, all pregnant women were given iron supplements (100 mg as ferrous sulphate and $500 \mathrm{mg}$ folic acid) orally once a day, daily for 100 days. After three weeks of iron supplementation, we assessed $\mathrm{Hb}$; if $\mathrm{Hb}$ did not raise then the subjects were excluded from the study and referred to other investigations. All blood collections were done in the Department of Obstetrics \& Gynaecology, King George"s Medical University, Lucknow, U.P., India. The subjects were instructed not to change their dietary or activity habits during the study. After deworming, venous blood of all women (non-anemic and anemic) were taken for the estimation of biomarkers of blood index values, iron status, lipid profiles and oxidative stress parameter (pretreatment). All tests were repeated after 100 days of treatment (post-treatment).

\section{Sample Collection}

$6 \mathrm{ml}$ venous blood was taken from each of the subjects and divided into three aliquots. One $\mathrm{ml}$ of blood was transferred to an evacuated tube containing EDTA solution used to determine $\mathrm{Hb}$ and Hct. Three milliliters of whole blood was also transferred into EDTA containing tube and then centrifuged; plasma separated and used for the estimation of Fe, LPO, total lipid, total cholesterol, HDL, LDL, VLDL, triglyceride and phospholipid. Serum from remaining $2 \mathrm{ml}$ blood after clotting separated out and collected in clean centrifuge tube and again centrifuged for five minutes at $3000 \mathrm{rpm}$. The serum thus obtained was used for the estimation of ferritin and transferring receptors levels.

\section{Analytical Estimation}

Blood haemoglobin was determined by using the cyanomethemoglobin method [18]. Haematocrit (Hct) was determined by using Sysmax A-380 automated cell counter. The concentration of iron in plasma was measured with flame atomic absorption spectrophotometer (Perkin Elmar AAS-700 Ueberlinger, Germany) [19]. Serum ferritin and serum transferrin receptor levels were determined by enzyme-linked immunosorbentassay kits (Spectro Ferritin, S-22 and TfR, TF-94, Ramco Laboratories Inc, Houston, Texas, USA). Serum total lipid, total cholesterol, high-density lipoprotein, triacylglycerol and phospholipids were determined using Randox Laboratory kit reagents and VLDL was calculated using the formula $\mathrm{TG} / 2.2 \mathrm{mmol} / \mathrm{L}$. Low density lipoprotein (LDL) cholesterol was determined by differential substraction of the sum of the cholesterol fractions from the total cholesterol.

Statistical Analysis: Healthy pregnant women (control) and pregnant anemic women (mild, moderate and severe) before and after treatment were compared together using one-way ANOVA analysis of variance by Neuman-Keules post hoc test between groups. A probability p-value of $<$ $0.05(p<0.05)$ was considered statistically significant. The statistical analysis was performed on commercial software INSTAT 3.0, a demo version (Graph Pad Software, San Diego, CA). 


\section{International Journal of Science and Research (IJSR) \\ ISSN (Online): 2319-7064 \\ Index Copernicus Value (2013): 6.14 | Impact Factor (2014): 5.611}

\section{Results}

Effect of Iron and Folic Acid Supplementation on Anemic Markers in Pregnant Anemic Women

The pre and post-treatment bold index parameters of all pregnant healthy and anemic women are summarized in Table 2. The Haemoglobin $(\mathrm{Hb})$ level in venous blood of healthy pregnant women was $12.19 \pm 0.90 \mathrm{mg} / \mathrm{dl}$. On the other hand, it was found decreased in , anemic condition ${ }^{\text {ee }}$ viz. mild $(14 \% ; \mathrm{p}<0.001)$, moderate $(34 \% ; \mathrm{p}<0.001)$ and severe $(49 \% ; \mathrm{p}<0.001)$ subjects. After treatment with iron and folic acid (100 mg and $500 \mathrm{mg} / \mathrm{d}$ ) for 100 days, the levels of $\mathrm{Hb}$ were reversed significantly in control $(10 \%$ : $\mathrm{p}<0.001)$, mild $(16 \% ; \mathrm{p}<0.001)$, moderate $(33 \% ; \mathrm{p}<0.001)$ and severe $(28 \% ; \mathrm{p}<0.001)$ pregnant anemic women. We also observed that haematocrit (Hct) in venous blood of control group was $35.84 \pm 5.43 \%$. However, this level was found significantly decreased in different groups of pregnant women, who were under anemic; such as mild $(13 \% ; \mathrm{p}<0.001)$, moderate $(20 \% ; \mathrm{p}<0.001)$ and severe $(35 \% ; \mathrm{p}<0.001)$. Treatment with iron and folic acid increased the level of Hct in control $(9 \% ; \mathrm{p}<0.01)$, mild $(11 \% ; \mathrm{p}<0.001)$, moderate $(13 \% ; \mathrm{p}<0.001)$ and severe $(13 \% ; \mathrm{p}<0.001)$ men. Similarly, iron $(\mathrm{Fe})$ level in blood plasma of mild $(10 \% ; \mathrm{p}<0.01)$, moderate $(43 \% ; \mathrm{p}<0.001)$ and severe $(68 \% ; \mathrm{p}<0.001)$ anemic pregnant women was found decreased as compared with control group. Treatment with the drug restored the levels of Fe in control $(44 \% ; \mathrm{p}<0.001)$, mild $(40 \% ; \mathrm{p}<0.001)$, moderate $(35 \%$; $\mathrm{p}<0.001)$ and severe $(32 \% ; \mathrm{p}<0.05)$ women.

Ferritin levels in blood serum of control group were 37.72 $\pm 12.96 \mu \mathrm{g} / \mathrm{L}$. On the other hand, these levels were found significantly decreased in different groups of pregnant anemic women, i.e. mild $(10 \% ; \mathrm{p}<0.01)$, moderate $(46 \%$; $\mathrm{p}<0.001)$ and severe $(68 \% ; \mathrm{p}<0.001)$ when compared with control. After treatment with elemental iron and folic acid (100 $\mathrm{mg}$ and $500 \mathrm{mg} / \mathrm{d}$ ) for 100 days showed a significant reversal in control, mild, moderate and severe by $(44 \%$; $\mathrm{p}<0.001),(40 \% ; \mathrm{p}<0.001),(35 \% ; \mathrm{p}<0.001)$ and $(32 \%$; $\mathrm{p}<0.05)$, respectively when compared with its respective pre-treated groups. We also observed sTfR level in blood serum of control group was $3.69 \pm 1.64 \mathrm{mg} / \mathrm{L}$. However, this level was found significantly increased in different groups of pregnant anemic women, such as mild $(15 \%$; $\mathrm{p}<0.01)$, moderate $(35 \% ; \mathrm{p}<0.001)$ and severe $(48 \%$; $\mathrm{p}<0.001)$. Treatment suppressed the level of sTfR in control $(41 \% ; \mathrm{p}<0.001)$, mild $(35 \% ; \mathrm{p}<0.001)$ moderate $(28 \% ; \mathrm{p}<0.001)$ and severe $(20 \% ; \mathrm{p}<0.01)$ pregnant women when compared with its respective pre-treatment subjects.

\section{Effect of Iron and Folic Acid Treatment on Lipid Profiles in Pregnant Anemic Women}

We observed alterations in the lipid profiles (TL) following iron and folic acid (100 mg and $500 \mathrm{mg} / \mathrm{d})$ for 100 days treatment (Table 3). In normal healthy pregnant women total lipid (TL) level was $9.77 \pm 3.30 \mathrm{mg} / \mathrm{dl}$, total cholesterol (TC) was $4.27 \pm 1.94 \mathrm{mmole} / \mathrm{L}$ and phospholipid (PL) was $2.25 \pm 0.31 \mathrm{mmole} / \mathrm{L}$. It was found that in iron deficient pregnant anemic women viz. mild, moderate and severe patients there was a decline in their TL level by $10 \%(p>0.05), 40 \% \quad(p<0.001)$ and $61 \%$ $(p<0.001)$; TL by $8 \%(p>0.05), 19 \%(p>0.05)$ and $29 \%$ $(\mathrm{p}<0.01)$ and PL by $2 \%(\mathrm{p}>0.05), 7 \%(\mathrm{p}<0.05)$ and $9 \%$ $(\mathrm{p}<0.01)$, respectively as compared with control. Treatment of above mentioned subjects with iron and folic acid showed reversal of above aforementioned lipid parameters. Our results showed that following treatment, the TL levels of control, mild, moderate and severe anemic women were significantly increased by $27 \%(p<0.001)$, $28 \% \quad(p<0.001), 41 \% \quad(p<0.001)$ and $34 \% \quad(p<0.05)$, respectively when compared with their respective pre treatment parameters. Similarly, TC levels were also found significantly increased by $38 \%(\mathrm{p}<0.001), 39 \%(\mathrm{p}<0.001)$, $44 \%(p<0.001)$ and $41 \%(p<0.05)$. PL levels were also increased in post treated patients when compared with its pre treated groups. It was observed that the triglyceride (TG) level in blood plasma of control was $1.28 \pm 0.20$ mmole/L. However, these levels in pre treated mild, moderate and severe anemic pregnant women were increased by $7 \%(p<0.05), 18 \% \quad(p<0.001)$ and $33 \%$ $(p<0.001)$, respectively. Furthermore, after treatment the levels of TG were elevated in control $(9 \% ; \mathrm{p}<0.01)$, mild $(7 \% ; \mathrm{p}<0.05)$, moderate $(4 \% ; \mathrm{p}>0.05)$ and severe $(5 \%$; $\mathrm{p}>0.05)$ pregnant women when compared with their respective pre treated levels. Table 3 shows that the pretreatment mean levels of lipid peroxide in the blood plasma of pregnant non-anemic women (control) was 2.33 $\pm 0.31 \mathrm{nmole} \mathrm{MDA} / \mathrm{mg}$ protein. The pre-treatment mean levels of these parameters were significantly $(p<0.01$ or $\mathrm{p}<0.001$ ) increased in all groups of anemic women when compared with controls. Furthermore, after treatment the levels of LPx were also elevated in control (24\%; $\mathrm{p}<0.001)$, mild $(19 \% ; \mathrm{p}<0.001)$, moderate $(11 \% ; \mathrm{p}<0.001)$ and severe $(9 \% ; \mathrm{p}<0.01)$ women when compared with respective pretreated levels.

\section{Status of Blood Plasma Lipoproteins before and After Treatment with Iron and Folic Acid in Pregnant Women}

Table 4 shows that the levels of lipoproteins like LDL and VLDL in the blood plasma of pregnant non-anemic women (control) were $2.23 \pm 0.51 \mathrm{mmole} / \mathrm{L}, 0.287 \pm 0.07$ mmole/L, respectively. These parameters were significantly increased in all groups of anemic women when compared with controls. Treatment with iron and folic acid further increased the levels of LDL in control $(\mathrm{p}<0.05)$, mild, moderate and severe women. Furthermore, after treatment the levels of VLDL were also elevated in control, mild, moderate and severe anemic women when compared with pre-treated levels. We also observed that the level of HDL in the non-anemic women (control) was $1.45 \pm 0.44 \mathrm{mmole} / \mathrm{L}$. This parameter was decreased in all pre-treated groups of anemic women as compared with controls. After treatment these were further decreased in control, mild, moderate and severe anemic and non anemic women when compared with pre-treatment levels.

\section{Pregnancy Outcomes after Treatment}

Birth outcomes after medication with iron and folic acid are depicted in Table 5. Our results showed that the term 


\section{International Journal of Science and Research (IJSR) \\ ISSN (Online): 2319-7064}

Index Copernicus Value (2013): 6.14 | Impact Factor (2014): 5.611

delivery was present in $88 \%$ with control, $84 \%$ of women with mild anemia, $85 \%$ with moderate and $83 \%$ in severe anemia. Preterm delivery was occurred in $12 \%, 16 \%, 15 \%$ and $17 \%$ of control, mild, moderate and severe subjects, respectively. Mode of delivery like normal vaginal was encountered in $71 \%, 77 \%, 82 \%$ and $87 \%$ of control, mild, moderate and severe post treated groups. Instrumental and cesarean delivery were occurred in $8 \%, 7 \%, 4 \%$ and $2 \%$ and $21 \%, 16 \%, 14 \%$ and $11 \%$ of control, mild, moderate and severe patients after treatment. Our results were also found that the baby birth weight of control was $2823.62 \pm$ $367 \mathrm{~g}$. This birth weight was non-significantly decreased in mild and moderate pregnant anemic patients except severe group $(\mathrm{p}<0.05)$ when compared with post treated control subjects.

\section{Discussion}

Pregnancy generally induces significant metabolic changes. The concentrations of lipids, lipoproteins and apolipoproteins in the plasma increase appreciably during pregnancy, principally affected by maternal hormonal changes such as rise in insulin, progesterone, 17- $\beta$ estradiol and human placental lactogen. The data of the present study reported that treatment of iron deficient anemic women with oral iron $(100 \mathrm{mg})$ and folic acid (500 $\mu \mathrm{g}$ ) daily for 100 days significantly improved $\mathrm{Hb}$ and and Hct levels. Recovery of $\mathrm{Hb}$ after supplementation of iron with folic acid in patients may be due to the fact that iron is an essential constituent of heame and folic acid enhances the erythropoietic mechanism [20]. Plasma iron levels were observed to be significantly decreased in anemic women and recovered enormously in all supplemented groups. Women of reproductive age lose iron during menses, and having a substantially higher need for iron during pregnancy, because of the increase in red cell volume of the mother and placental and fetal growth [21]. Ministry of Health, Government of India has recommended intake of $100 \mathrm{mg}$ of iron and $500 \mu \mathrm{g}$ of folate per day for 100 days in the second half of pregnancy [22]. Tiwari et al. [23] and King et al.[24] had also reported that daily oral iron, in form of ferrous sulphate $(100 \mathrm{mg})$ with folic acid $(500 \mu \mathrm{g})$ daily for 100 days and $98 \mathrm{mg}$ of ferrous sulphate alone for 56 days daily improved iron in iron deficient women. Present finding showed that ferritin levels were found decreased in different group of pregnant anemic women, however, serum transferrin receptor levels (sTfR) were registered to increase in these subjects. Treatment significantly revert the levels of above aforementioned parameters. Present results are similar to previous reports [25-26]. Serum TfR is the most sensitive indicator of iron status when there is tissue iron deficiency and the serum ferritin concentration is the most sensitive indicator of iron status when there are residual iron stores. The sTfR concentration is usually increased owing to iron deficiency, leading to insufficient supplies of iron to the bone marrow. The consistent decrease in sTfR in the iron supplemented group was probably due to an increase in iron supply by the iron capsules, or to a decrease in iron demand while the iron stores were being replenished.
In the present study, we also observed significantly increased levels of plasma lipid peroxide levels (LPx) in women with iron deficiency anemia and further elevated after treatment. Moreover, we found that in the control and mild group less iron is utilized instead of moderate and severe anemic patients, which leads to make available more free iron in the body that in term may eventually further enhance the oxidative stress levels in this group. There have been reports that lipid peroxidation was significantly accelerated in iron deficiency anemia [27-28]. It is well known that lipid peroxidation is a free radicalmediated phenomenon and that the lipids in RBCs are susceptible to peroxidation in the pathophysiology of iron deficiency anemia. There are reports that the iron doses used for correcting iron deficiency anemia may further elevate the lipid peroxidation products, mainly due to increased bioavailability of elemental free iron in gastrointestinal mucosal cells of the subjects [20-23].

We observed alterations in the lipid profiles in iron deficient pregnant anemic women (Table 3). The concentration of total lipid, total cholesterol and phospholipid were found to be significantly decreased in pregnant anemic women. The reduction of lipids may be correlated with the iron deficiency anemia induced increased lipid peroxidation. These results are similar to those reported earlier in pre-eclampsic pregnant women [29]. It may be suggested that an excess of ROS in iron deficient patients caused the oxidative degradation of RBC lipids resulting in decreased level of lipids in these patients. The RBC is an important source of oxygenrelated radicals in iron deficiency anemia (IDA). However, IDA, RBCs produces greater quantities of $\mathrm{O}_{2}{ }^{-}, \mathrm{H}_{2} \mathrm{O}_{2}$ and $\mathrm{OH}^{\circ}$ than do normal RBC [30]. Besides, iron deficiency anemia, RBCs exhibit increased levels of thiobarbituric acid-reactive substances, suggesting that they are targets for oxidative stress [31]. During deoxygenation of haemoglobin, there is a transfer of electrons between iron atom and $\mathrm{O}_{2}$ leading to the production of $\mathrm{O}_{2}{ }^{--}$. Physiological auto-oxidation of haemoglobin also leads to the production of free radicals. Within the $\mathrm{RBC}$, one of the targets of oxidant damage is the plasma membrane. In the presence of $\mathrm{O}_{2}{ }^{\cdot-}$ generating system, iron (III) is reduced to iron (II) with subsequent formation of $\mathrm{OH}^{\circ}$ and $\mathrm{H}_{2} \mathrm{O}_{2}$ [3031]. The hydroxyl radical oxidizes unsaturated esterified membrane lipids, resulting in changes in fluidity of the bilayer. Cholesterol in RBC membrane normally comprises more than $99 \%$ of the neutral lipids in $\mathrm{RBC}$ membrane, has been found to exchange freely between both the inner and outer layers of the bilayer and is in equilibrium with non-esterified (free) cholesterol attached to the plasma lipoproteins [32]. However, Zailaie et al. [33] reflected that increased rate of exchange between plasma cholesterol and RBCs membrane cholesterol may be due to loss of RBC membrane phospholipids asymmetry following increase in oxidative stress, allowing more plasma cholesterol to be incorporated in RBC membrane possibly to retain some of the loss in RBC membrane integrity. After treatment with iron a significant enhancement in lipid levels of blood plasma profile was observed as compared with pre-treatment groups. These results are consistent with the reports of investigators [1334], demonstrating that dietary iron supplementation 


\section{International Journal of Science and Research (IJSR) \\ ISSN (Online): 2319-7064}

Index Copernicus Value (2013): 6.14 | Impact Factor (2014): 5.611

increases plasma lipids in iron deficient girls and in rats. Ohira et al. [35] found that total cholesterol concentrations were elevated following an increase in haemoglobin levels by transfusion and iron treatment. They also reported that the concentration of red blood cells might affect cholesterol synthesis or its mobilization from tissue to plasma.

Triglycerides were found to be elevated in iron deficient anemic women as compared with the controls and further increased after oral iron treatment. The increase in serum TG may be due to hypoactivity of lipoprotein lipase in blood vessels that breaks up TG. The concentration of HDL was found to be reduced following iron deficiency anemia and after iron supplementation (Table 4). Increased levels of LPO or VLDL and LDL in pre treated patients and even maximum increment of these lipoproteins in control and mild post treated subjects as compare to moderate and severe anemic patients are known to be cytotoxic to cells and tissues. Recently it has been emphasized that hyperlipemic $\beta$-lipoproteins are cytotoxic to cells and tissues presumably due to enhanced levels of associated LPO [36]. Lipids play significant role in various disorders like cardiovascular, hyperlipidemia fatty liver. It modifies the composition, structure, and stability of cellular membranes. Excess lipid in the blood is considered to accelerate the development of arteriosclerosis. An altered lipid metabolism can alter the cardiac function by changing the properties of cardiac cell membrane and these changes may contribute to the cell death. Recent reports indicate that cytotoxicity induced by LDL and VLDL can result from lipoprotein oxidation. Ultimately indicated by the relative amount of MDA equivalents or thiobarbituric acid-reacting substances (TBARS) residing on the lipoprotein [37].

Contrary the results of Salonen et al. [38], which would suggest that persons with iron deficiency should not be treated with supplements due to possible adverse events, the results of the present experimental study showed that measures of oxidative stress were affected by a therapeutic dose of iron in women with low iron status. This study clearly demonstrates that the levels of LPO, LDL and VLDL were increased maximum in control and mild than remaining groups because less iron is utilized in these groups due to different individual requirements facilitates the increasing oxidative stress. However, we can say that $100 \mathrm{mg}$ of iron is excess for control and mild groups as moderate and severe patients. In our study, Iron status was improved as shown by an increase in ferritin, which is the most reliable marker of iron status, although the lipoproteins oxidation were affected by supplement intake in control and mild group instead of moderate and severe.

\section{Conclusion}

The results indicate that a therapeutic dose of iron affect measures of oxidative stress despite improved iron status in subjects receiving the supplement as considered by a significant increase in ferritin, and hemoglobin with alteration in lipid profiles and lipoproteins, although the support a probable relationship between iron status and lipoproteins oxidation is affected by aggressive supplementation with iron to improve iron status. Iron supplementation, at the dose we used, independently affects LDL oxidative susceptibility. Conclusively, as excess iron in fact plays a role in increasing risk of LDL oxidation during pregnancy.

\section{Conflict Of Interest}

None

\section{Acknowledgement}

Financial support from Council of Science \& Technology, Uttar Pradesh as Ad-hoc research scheme No. CST/SERPD/D-3407

\section{References}

[1] de Valk B, Addicks MA, Gosriwatana I, Lu S, Hider RC, Marx JJ. Nontransferrin- bound iron is present in serum of hereditary haemochromatosis heterozygotes. Eur J Clin Invest 2000; 30: 248-251.

[2] Vaya A, Iborra J, Falco C, Moreno I, Bolufer P, Ferrando F, Perez ML, Justo Aznar. Rheological behaviour of red blood cells in beta and deltabeta thalassemia minor. Clin Hemorheol Microcirc 2003; 28: 71-8.

[3] Vives Corrons, JL, Miguel-Garcia A, Pujades MA, Miguel-Sosa A, Cambiazzo S, Linares M, Dibarrart MT, Calvo MA. Increased susceptibility of microcytic red blood cells to in vitro oxidative stress. Eur J Haematol 1995; 55: 327-31.

[4] Stadtman ER, Levine RL. Protein oxidation. Ann NY Acad Sci 2000; 899: 191-208.

[5] Chiu D, Kuypers F, Lubin B. Lipid Peroxidation in Human Red Cells. Semin Hematol 1989; 25: 257-276.

[6] Sanghani SP, Haldankar VA, Shalia KK Bichile SK. Comparative analysis of $\mathrm{RBC}$ membrane lipids in thalassemia and iron deficiency anemia in relation to hypochromia and oxidant injury. Ind $\mathrm{J}$ Clin Biochem 2001; 16: 116-121.

[7] Li JY, Li JX, Yang ZM. Abnormalities of ionexchange proteins of the red cell membrane in iron deficiency anemia. Clin Med J 1992; 105: 116-119.

[8] Brizzi P, Tonolo G, Esposito F et al. Lipoprotein metabolism during normal pregnancy. Am J Obstet Gynaecol 1999; 181: 430-434.

[9] Kaaja R. Insulin resistance syndrome in preeclampsia. Sem Reprod Endocrinol 1998; 16: 41-46.

[10] Toescu V, Nuttall SL, Martin U, Kendall MJ, Dunne F. Oxidative stress and normal pregnancy. Clin Endocrinol (Oxford) 2002; 57: 609-613.

[11] Salonen JT, Nyyssonen K, Korpela H, Tuomilehto J, Seppanen R, Salonen R. High stored iron levels are associated with excess risk of myocardial infarction in eastern Finnish men. Circulation 1992; 86: 803-811.

[12] Magnusson MK, Sigfusson N, Sigvaldason $H$, Johanneson GM, Magnusson S, Thorgeirsson G. Low iron binding capacity as a risk factor for myocardial infarction. Circulation 1994; 89: 102-108.

[13] Choi JW, Kim SK, Pai SH. Changes in Serum Lipid Concentrations during Iron Depletion and after Iron 


\section{International Journal of Science and Research (IJSR) \\ ISSN (Online): 2319-7064}

Index Copernicus Value (2013): 6.14 | Impact Factor (2014): 5.611

Supplementation. Ann Clin Lab Sci 2001; 31: 151156.

[14] Tanzer F, Hizel S, Cetinkaya O, et al. Serum free carnitine and total triglyceride levels in children with iron deficiency anemia. Int J Vitam Nutr Res. 2001; 71: 66-69.

[15] Diana FM, Loke OAC, Viegas LP, Kek M, Rauff AC, Thai SS, Ratnam. Lipid profiles during and after normal pregnancy. Gynecol Obst Invest Vol. 32, No. 3, 1991 .

[16] Choi JW, Pai SH. Serum lipid concentrations change with serum alkaline phosphatase activity during pregnancy. Ann Clin Lab Sci 2000; 30(4): 422-8.

[17] World Health Organization (WHO)/United Nations Children"s Fund/United Nations University. Iron deficiency: indicators for assessment and strategies for prevention. Geneva: WHO, 1998.

[18] International Nutritional Anemia Consultative Group (INACG). Measurements of iron status. Washington, DC: INACG, 1985.

[19] Brown A, Halls JD, Taylor A. A atomic pectrometry update-clinical materials, foods and beverages. J Analy Atomic Spectrometry 1986; 1: 21-35.

[20]Brittenham GM. Disorder of iron metabolism: iron deficiency and iron overload, in Hematology: Basic principles and practice, Hoffman RE, Benz J, JR; SJ. Shattil et al., eds; Churchill Livingstone, Philadelphia, 2000, page 416 .

[21] Bothwell TH. Iron requirements in pregnancy and strategies to meet them. Am J Clin Nutr 2000; 72: $257 \mathrm{~S}-64 \mathrm{~S}$.

[22] Sharma JB. Nutritional Anemia during Pregnancy in non-industrialized countries. Prog Obst Gynecol 2003; 15: 103-114.

[23] Tiwari AKM, Mahdi AA, Chandyan S, Zahra F, Godbole MM, Jaiswar SP, Srivastava VK, Negi MPS. Oral iron supplementation leads to oxidative imbalance in anemic women: A prospective study. Clin Nutr 2011; 30: 188-193.

[24] King SM, Donangelo CM, Knutson MD, Walter PB, Ames BN, Viteri FE, et al. Daily supplementation with iron increases lipid peroxidation in young women with low iron stores. Soc for Exp Biol Med 2008; 70: 1-7.

[25] Nair KM, Bhaskaram P, Balakrishna N, Punjal R, Boindala S. Response of hemoglobin, serum ferritin and serum transferrin receptor during iron supplementation in pregnancy: a prospective study. Nutrition 2004; 20: 896-899.

[26] Cogswell ME, Parvanta I, Ickes L, Yip R, Brittenham GM. Iron supplementation during pregnancy, anemia and birth weight: a randomized controlled trail. Am J Clin Nutr 2003; 78: 773.

[27] Tiwari AKM, Mahdi AA, Zahra F, Chandyan S, Srivastava VK, Negi MPS. Evaluation of oxidative stress and antioxidant status in pregnant anemic women. Ind J Clin Biochem 2010; 25(4): 411-418.

[28] Sundaram RC, Selvaraj N, Vijayan G, Bobby Z, Hamide A, Rattina DN. Increased plasma malondialdehyde and fructosamine in iron deficiency anemia: Effect of treatment. Biomed Pharmacother 2007; 61: 682-5.

[29] Aziz R, Mahboob T. Pre-eclampsia and lipid profile. Pak J Med Sci 2007; 23: 751-754.

[30] Habbel RP, Eaton JW, Balasingam M, Steinberg MH. Spontaneous oxygen radical generation by sickle erythrocytes. J Clin Invest 1982; 70: 1253-1259.

[31] Aslan M, Thornley-Brown D, Freeman BA. Reactive species in sickle cell disease. Ann N Y Acad Sci 2000; 899: 375-391.

[32] Norum KR, Gjone E. Familial plasma lecithin acyl transferase deficiency. Biochemical study of a new inborn error of metabolism. Scand J Clin Lab Invest 1967; 20: 231-235.

[33]Zailaie MZ, Marzouki ZM, Khoja SM. Plasma and red blood cells membrane lipid concentration of sickle cell disease patients. Saudi Med J 2003; 24: 376-379.

[34] Cunnane SC, McAdoo KR. Iron intake influences essential fatty acid and lipid composition of rat plasma and erythrocytes. J Nutr 1987; 117: 1514-1519.

[35] Ohira Y, Edgerton VR, Gardner GW, Senewiratne B. Serum lipid levels in iron deficiency anemia and effects of various treatments. J Nutr Sci Vitaminol 1980; 26: 375-379.

[36] Steinberg D. Lewis A. Conner Memorial Lecture. Oxidative modification of. LDL and atherogenesis. Circulation 1997; 95: 1062-1071.

[37] McCord JM. Effects of positive iron status at a cellular level. Nutr Rev 1996; 54: 85-88.

[38] Salonen, JT, Nyyssonen K, Korpela H, Tuomilehto J, Seppanen R, Salonen R. High stored iron levels are associated with excess risk of myocardial infarction in eastern Finnish men. Circulation 1992; 86: 803-811 


\section{International Journal of Science and Research (IJSR) \\ ISSN (Online): 2319-7064}

Index Copernicus Value (2013): 6.14 | Impact Factor (2014): 5.611

Table 1: Characteristics of the subjects

\begin{tabular}{|c|c|c|c|c|}
\hline Characteristics & Control $(\mathrm{n}=100)$ & Mild $(n=100)$ & Moderate $(n=100)$ & Severe $(n=50)$ \\
\hline Age (yrs) & $26.12 \pm 6.21$ & $25.37 \pm 7.71$ & $25.88 \pm 6.54$ & $24.15 \pm 5.17$ \\
\hline Height $(\mathbf{c m})$ & $150.55 \pm 4.52$ & $150.16 \pm 4.48$ & $149.73 \pm 3.34$ & $150.02 \pm 4.19$ \\
\hline \multicolumn{5}{|c|}{ Literacy (\%) illiterate } \\
\hline$<10^{\text {th }}$ grade & $46(46 \%)$ & $51(51 \%)$ & $47(47 \%)$ & $23(46 \%)$ \\
\hline$>10^{\text {th }}$ grade & $54(54 \%)$ & $49(49 \%)$ & $53(53 \%)$ & $27(54 \%)$ \\
\hline \multicolumn{5}{|c|}{ Parity (\%) } \\
\hline $1^{\text {st }}$ Pregnancy & $16(16 \%)$ & $13(13 \%)$ & $11(11 \%)$ & $12(24 \%)$ \\
\hline$\geq 2^{\text {nd }}$ Pregnancy & $86(86 \%)$ & $87(87 \%)$ & $89(86 \%)$ & $38(76 \%)$ \\
\hline \multicolumn{5}{|c|}{ History of miscarriages (\%) } \\
\hline Yes & $10(10 \%)$ & $13(13 \%)$ & $15(15 \%)$ & $7(14 \%)$ \\
\hline No & $90(90 \%)$ & $87(87 \%)$ & $85(85 \%)$ & $43(86 \%)$ \\
\hline \multicolumn{5}{|c|}{ Socioeconomic status (\%) } \\
\hline Low & $15(15 \%)$ & $20(20 \%)$ & $21(21 \%)$ & $16(32 \%)$ \\
\hline Middle & $69(69 \%)$ & $63(63 \%)$ & $65(65 \%)$ & $28(56 \%)$ \\
\hline High & $16(16 \%)$ & $17(17 \%)$ & $14(14 \%)$ & $6(12 \%)$ \\
\hline \multicolumn{5}{|c|}{ Occupation (\%) } \\
\hline Housewife & $97(97 \%)$ & $98(98 \%)$ & $97(97 \%)$ & $50(100 \%)$ \\
\hline Informal business & $0(0 \%)$ & $0(0 \%)$ & $0(0 \%)$ & $0(0 \%)$ \\
\hline Employee/students & $3(3 \%)$ & $2(2 \%)$ & $3(3 \%)$ & $0(0 \%)$ \\
\hline $\begin{array}{l}\text { Gestational age at } \\
\text { recruitment (wk) }\end{array}$ & $21.33 \pm 2.56$ & $19.72 \pm 3.18$ & $21.36 \pm 2.32$ & $22.61 \pm 3.15$ \\
\hline
\end{tabular}

Table 2: Blood index values (mean \pm SD) before and after iron and folic acid supplementation in subjects

\begin{tabular}{|c|c|c|c|c|c|c|c|c|}
\hline \multirow[t]{2}{*}{ Parameters } & \multicolumn{2}{|c|}{ Control $(\mathrm{N}=100)$} & \multicolumn{2}{|c|}{ Mild $(N=100)$} & \multicolumn{2}{|c|}{ Moderate $(\mathrm{N}=100)$} & \multicolumn{2}{|c|}{ Severe $(N=50)$} \\
\hline & Pre & Post & Pre & Post & Pre & Post & Pre & Post \\
\hline $\mathrm{Hb}$ & $12.19 \pm 0.90$ & $13.46 \pm 1.22^{4 * *}$ & $10.49 \pm 0.23^{\mathrm{a}}$ & $12.18 \pm 0.59^{* * *}$ & $8.03 \pm 0.54^{\mathrm{a}}$ & $10.70 \pm 1.20^{* * *}$ & $6.73 \pm 0.22^{\mathrm{a}}$ & $8.65 \pm 0.67^{* 4 *}$ \\
\hline Hct & $35.84 \pm 5.43$ & $39.08 \pm 5.47^{* * *}$ & $31.06 \pm 2.77^{\mathrm{a}}$ & $34.44 \pm 2.93^{* * *}$ & $28.55 \pm 3.86^{\mathrm{a}}$ & $32.52 \pm 3.46^{* 4 *}$ & $23.19 \pm 2.25^{\mathrm{a}}$ & $26.12 \pm 2.77^{* * *}$ \\
\hline $\mathrm{Fe}$ & $41.94 \pm 7.56$ & $58.87 \pm 10.62^{4 * *}$ & $38.86 \pm 8.32^{b}$ & $51.30 \pm 9.37^{4 * *}$ & $23.97 \pm 5.42^{\mathrm{a}}$ & $30.47 \pm 6.40^{4 * *}$ & $19.64 \pm 3.04^{\mathrm{a}}$ & $24.12 \pm 3.34^{* *}$ \\
\hline Ferritin & $37.72 \pm 12.96$ & $54.38 \pm 11.92^{* * *}$ & $34.04 \pm 8.96^{b}$ & $47.66 \pm 10.12^{* * *}$ & $20.46 \pm 8.44^{\mathrm{a}}$ & $27.65 \pm 10.18^{* 4 *}$ & $11.99 \pm 3.06^{\mathrm{a}}$ & $15.88 \pm 3.15^{*}$ \\
\hline TfR & $3.69 \pm 1.64$ & $2.19 \pm 0.90^{4 * *}$ & $4.26 \pm 1.80^{b}$ & $2.78 \pm 1.33^{* 4 *}$ & $4.99 \pm 1.79^{\mathrm{a}}$ & $3.59 \pm 1.39^{* * *}$ & $5.46 \pm 1.74^{\mathrm{a}}$ & $4.38 \pm 1.56^{4 *}$ \\
\hline
\end{tabular}

Haemoglobin $(\mathrm{Hb})$ and iron $(\mathrm{Fe})$ are expressed in $\mathrm{mg} / \mathrm{dl}$. The values of Haematocrit (Hct), ferritin and sTfR (serum transferring receptor levels) are expressed in $\%, \mu \mathrm{g} / \mathrm{L}$ and $\mathrm{mg} / \mathrm{L}$, respectively.

Significance: ${ }^{\mathrm{a}} \mathrm{P}<0.001$ and ${ }^{\mathrm{b}} \mathrm{P}<0.01$ as compared with the pre control group.

${ }^{*} \mathrm{P}<0.05,{ }^{* *} \mathrm{P}<0.01$ and ${ }^{* * *} \mathrm{P}<0.001$ as compared with the pre treatment group.

Pre $=$ pre treatment; Post $=$ post treatment

Table 3: Lipid profiles (mean \pm SD) before and after iron and folic acid supplementation in subjects

\begin{tabular}{|c|c|c|c|c|c|c|c|c|}
\hline \multirow[t]{2}{*}{ Parameters } & \multicolumn{2}{|c|}{ Control $(\mathrm{N}=100)$} & \multicolumn{2}{|c|}{ Mild $(\mathrm{N}=100)$} & \multicolumn{2}{|c|}{ Moderate $(\mathrm{N}=100)$} & \multicolumn{2}{|c|}{ Severe $(N=50)$} \\
\hline & Pre & Post & Pre & Post & Pre & Post & Pre & Post \\
\hline TL & $9.77 \pm 3.30$ & $12.44 \pm 3.21^{* * *}$ & $8.75 \pm 2.53$ & $11.19 \pm 2.74^{* * *}$ & $5.85 \pm 2.49^{\mathrm{a}}$ & $8.26 \pm 2.84^{* * *}$ & $3.81 \pm 1.82^{\mathrm{a}}$ & $5.11 \pm 1.81^{*}$ \\
\hline $\mathrm{TC}$ & $4.27 \pm 1.94$ & $5.89 \pm 2.41^{4 * *}$ & $3.93 \pm 1.88$ & $5.48 \pm 2.46^{4 * 4}$ & $3.45 \pm 1.63$ & $4.96 \pm 1.96^{* * *}$ & $3.02 \pm 1.13^{b}$ & $4.27 \pm 1.69^{*}$ \\
\hline TG & $1.28 \pm 0.20$ & $1.40 \pm 0.18^{* *}$ & $1.37 \pm 0.22$ & $1.47 \pm 0.20^{* *}$ & $1.51 \pm 0.35^{b}$ & $1.57 \pm 0.35^{*}$ & $1.70 \pm 0.31^{b}$ & $1.78 \pm 0.30$ \\
\hline PL & $2.25 \pm 0.31$ & $2.36 \pm 0.35$ & $2.20 \pm 0.33$ & $2.26 \pm 0.34$ & $2.10 \pm 0.41^{c}$ & $2.19 \pm 0.42$ & $2.04 \pm 0.29^{b}$ & $2.10 \pm 0.28$ \\
\hline LPx & $2.33 \pm 0.31$ & $2.88 \pm 0.39^{* * *}$ & $2.57 \pm 0.43^{b}$ & $3.05 \pm 0.49^{* * *}$ & $3.13 \pm 0.75^{\mathrm{a}}$ & $3.49 \pm 0.85^{* 4 *}$ & $4.15 \pm 0.73^{\mathrm{a}}$ & $4.52 \pm 0.78^{* *}$ \\
\hline
\end{tabular}

Volume 5 Issue 1, January 2016

www.ijsr.net 


\section{International Journal of Science and Research (IJSR) \\ ISSN (Online): 2319-7064 \\ Index Copernicus Value (2013): 6.14 | Impact Factor (2014): 5.611}

Total lipid (TL) is expressed in mg/dl. Total cholesterol (TC), triglyceride (TG) and phospholipids (PL) are expressed in mmole/L. Lipid peroxide levels is expressed in nmole MDA/mg protein.

Significance: ${ }^{\mathrm{a}} \mathrm{P}<0.001,{ }^{\mathrm{b}} \mathrm{P}<0.01$ and ${ }^{\mathrm{c}} \mathrm{P}<0.05$ as compared with the pre control group.

${ }^{*} \mathrm{P}<0.05,{ }^{* *} \mathrm{P}<0.01$ and ${ }^{* * *} \mathrm{P}<0.001$ as compared with the pre treatment group.

Pre $=$ pre treatment; Post $=$ post treatment

Table 4: Lipoprotein index profiles (mean \pm SD) before and after iron and folic acid supplementation in subjects

\begin{tabular}{|c|c|c|c|c|c|c|c|c|}
\hline \multirow[t]{2}{*}{ Parameters } & \multicolumn{2}{|c|}{ Control $(\mathrm{N}=100)$} & \multicolumn{2}{|c|}{ Mild $(N=100)$} & \multicolumn{2}{|c|}{ Moderate $(\mathrm{N}=100)$} & \multicolumn{2}{|c|}{ Severe $(N=50)$} \\
\hline & Pre & Post & Pre & Post & Pre & Post & Pre & Post \\
\hline LDL & $2.23 \pm 0.51$ & $2.43 \pm 0.55^{*}$ & $2.36 \pm 0.56$ & $2.58 \pm 0.60$ & $2.48 \pm 0.61^{c}$ & $2.67 \pm 0.59$ & $2.62 \pm 0.62^{\mathrm{a}}$ & $2.78 \pm 0.65$ \\
\hline VLDL & $0.287 \pm 0.07$ & $0.295 \pm 0.07$ & $0.302 \pm 0.08$ & $0.310 \pm 0.08$ & $0.345 \pm 0.12^{b}$ & $0.351 \pm 0.12$ & $0.435 \pm 0.17^{\mathrm{a}}$ & $0.440 \pm 0.17$ \\
\hline HDL & $1.45 \pm 0.44$ & $1.34 \pm 0.42$ & $1.40 \pm 0.38$ & $1.30 \pm 0.37$ & $1.34 \pm 0.33$ & $1.25 \pm 0.33$ & $1.25 \pm 0.28$ & $1.17 \pm 0.29$ \\
\hline
\end{tabular}

The value of low density lipoprotein (LDL) is expressed in $\mathrm{mg} / \mathrm{dl}$. Very low density lipoprotein (VLDL), high density lipoprotein (HDL) and phospholipids (PL) are expressed in mmole/L.

Significance: ${ }^{a} \mathrm{P}<0.001,{ }^{b} \mathrm{P}<0.01$ and ${ }^{\mathrm{c}} \mathrm{P}<0.05$ as compared with the pre control group.

${ }^{*} \mathrm{P}<0.05$ as compared with the pre treatment group.

Pre $=$ pre treatment; Post $=$ post treatment

Table 5: Birth outcomes in the post-treated groups

\begin{tabular}{lcccc} 
Variable & Control $(\mathrm{n}=100)$ & Mild $(\mathrm{n}=100)$ & Moderate $(\mathrm{n}=100)$ & Severe $(\mathrm{n}=50)$ \\
\hline & 88 & 84 & 85 & 83 \\
Term delivery (\%) & 12 & 16 & 15 & 17 \\
Preterm delivery (\%) & $2823.62 \pm 367$ & $77.7 \pm 441$ & $2727.3 \pm 457$ & 87 \\
Birth weight (g) & 71 & 7 & 82 & 2 \\
Mode of delivery (\%) & 8 & 16 & 4 & 11 \\
Normal vaginal delivery & 21 & & 14 & \\
Instrumental delivery & & & & 2 \\
Cesarean section & & & & \\
\end{tabular}

There were no significant differences between the groups. 